\title{
Implementing Custom Badamai Values as One of the Reference in Learning Civic Education at Senior High School in Banjarmasin
}

\author{
Mariatul Kiptiah \\ University Lambung Mangkurat \\ Banjarmasin, Indonesia \\ mariatulkiptiah.bjm@gmail.com \\ Bunyamin Maftuh \\ University Education Indonesia \\ Bandung, Indonesia
}

\author{
Elly Malihah \\ University Lambung Mangkurat \\ Banjarmasin, Indonesia \\ Iim Siti Masyitoh \\ University Lambung Mangkurat \\ Banjarmasin, Indonesia
}

\begin{abstract}
Custom badamai is one of dispute resolution way that is customarily done by Banjar society. It is defined as a result of the deliberation process in a purpose of attaining the decision as a problem-solving. Adat Badamai seems to be done in order to avoid the disputes that could be harmful to social order. The decision Badamai generated through the mechanism of consultation is an alternative attempt to find the problem-solving occurred in society. In Banjar community, as if there is the dispute among the citizens; the cruel or persecution; a fight or even traffic violations, then the citizens will tend to resolve through the way of badamai (adat badamai). Hence, the value of indigenous badamai might be implemented as a teacher reference in teaching and learning civic education at school, it is due to one of a particular topic in civic education which is democracy in Indonesia. In addition, on purpose to maintain and to uphold traditional customs which are believed to be the truth on society of Banjar, the students should have known and even implemented the value of custom badamai in their daily life.
\end{abstract}

Keyword; Values, custom badamai and learning civic education

\section{INTRODUCTION}

Banjarmasin is the multi-dimensional city and known as a commerce, government, educational and religious city. Any kind of traditional to modern shopping centers such as the floating market are in Banjarmasin. Both of the mayor and the governor office are built in the central Banjarmasin. As the educational city, there are a few of magnificent universities, public and private, formal and non-formal education.

Multiculturalism is not a political doctrine but rather as a pragmatic point of view of human life in order to respect the cultural diversity that must be manifested concretely in their social life. Multiculturalism is defined by [1] as having two meanings. First, it is a social reality in a heterogeneous society, and Second, multiculturalism means belief, ideology, attitudes, or a policy that respects pluralism and ethnic culture as something valuable, potential, which should be maintained and further developed. In line with him, [1] argued that the key word in this multiculturalism is a "difference" and an "appreciation", two words that have often confronted.

Custom badamai is one of dispute resolution way that is customarily done by Banjar society. It is defined as a result of the deliberation process for the purpose of attaining the decision as a problem-solving. Adat Badamai seems to be done in order to avoid the disputes that could be harmful to social order. The Badamai decision generated through the mechanism of consultation is an alternative attempt to find the problemsolving occurred in society. In Banjar community, as if there is the dispute among the citizens; the cruel or persecution; a fight or even traffic violations, then the citizens will tend to resolve through the way of badamai (adat badamai). The community reluctantly finished the dispute through a legitimate party [2].

Civic education, which is a compulsory subject at all levels of schooling, have a vision as a forming vehicle over the national characters (national and character building) and empower citizens with the mission of forming good citizens, who are able to do the rights and obligations of public life, nation and state in accordance with Pancasila and the 1945 Constitution. While indigenous Banjar communities stated that adat badamai Banjar can be proved by the evidence in the field by using several methods of research found the social life of Banjarmasin is heterogeneous both in terms of race, ethnicity or religion. Democratic values contained in the Indonesia philosophical foundation (Pancasila) so that these values are against the bureaucratical nation. Why democracy values and local culture (adat badamai values) is substantial for society or youth, since recently the characters and violence; vigilante among young people allegedly increased compared to before the social conflict among the youth, residential, tribes, and religion occurred in another area, more wide open to the readiness of the security forces are needed in the law enforcement process as part of the awareness of democracy for the people of diverse ethnicity, religion, ethnicity, and culture of the maturity of society and youth to democratic values and adat badamai can be realized in daily life. 
Ref. [3] suggested that in preparing the curriculum and teaching civics in schools should emphasize on four main principles, namely; (1) It should not become a tool of indoctrination politic of the government power; (2) It may develop a state of mind, the development of national character is the process of establishing smart citizens and high-power logic; (3) It seems to be the intellectual process; (4) It can be as a laboratory of democracy. In line, [4] proposed the idea to reposition Civics with three roles, one of which is through psycho-paedagogical development approach. This reasoning is based on the assumption that to educate children to be citizens who are intelligent and good should be done consciously and planned in a learning process so that they are actively developing the potential for him to have the spiritual power of religion, self-control, personality, intelligence, noble character, and skills needed him, society, nation, and state. So because of that reason, there is required that Civics teacher commitment in the development of civics lesson, one of them with the implementation of the customs value as a source of learning badamai civics is included in the theme of cultural learning democracy in Indonesia.

\section{METHODS}

The research conducted is qualitative, so that the data are collected and analyzed is descriptive, narrative, argumentative through exposure sentences. Of the reasons to select research methodology this qualitative because the data collected contains view deep people Banjar on the implementation of value customary badamai that cannot be achieved through size the calculation of figures. The use of this qualitative research methods influences the choice of determining the location of the study, the determination of the informant, type and source data as well as data collection and analysis techniques studied.

\section{RESULTS AND DISCUSSION}

While indigenous Banjar communities stated that adat badamai Banjar can be proved by the evidence in the field by using several methods of research found the social life of Banjarmasin is heterogeneous both in terms of race, ethnicity or religion. However, in the midst of such social conditions, it turns out people are able to understand the value of indigenous badamai good and orderly. It turned out that this condition is built based on the specific values of the orientation of the society, so as to understand the differences of social life in London.

The life of society and state could be the democracy value as cultural in daily life, since democracy is unity of thinking, attitude and manner of society which are followed by cultural value, equality, unity and brotherhood among society, community, ras, religion, and ethnic on purpose to cooperation, mutual trust, respect culturally diverse, tolerance and consensus.

Democratic values contained in the Indonesia philosophical foundation (Pancasila) so that these values are against the bureaucratical nation. Why democracy values and local culture (adat badamai values) is substantial for society or youth, since recently the characters and violence; vigilante among young people allegedly increased compared to before the social conflict among the youth, residential, tribes, and religion occurred in another area, more wide open to the readiness of the security forces are needed in the law enforcement process as part of the awareness of democracy for the people of diverse ethnicity, religion, ethnicity, and culture of the maturity of society and youth to democratic values and adat badamai can be realized in daily life.

Social plurality can be a major challenge for the government both in local and central in maintaining the regional position in order to create peacefulness and to avoid conflicts might be harmful to other people. Conflicts triggered by a lack of public awareness of differences in ethnicity, race, and religion, can lead to divisions in society as well as inevitable areas. As a form of conflict prevention, people should start aware and understand the differences revealed in every community, either a difference in terms of ethnicity, language or religion. The prevention process can be done by establishing their positive values contained within the community.

That statement is emphasized by Kelvin argument [5], that is

Values play a key role in guiding action, resolving conflicts, giving direction and coherence to life. Values are motivators, not only in daily actions but over the long haul... Values are important as guides in the bewildering world. But even if we lived in a more stable and that tranquil moment of history, values would still have prime importance because of their profound relation both to vitality and to the processes of human maturing.

The assumption from Kelvin addressed that value has the substantial role in human life, due to become guidance of life, a guidance of problem-solving, and guidance of motivation over human life. As if the value is positively raised, so it will assist human to be the better one.

The development of today's society requires every individual to be able to adjust the living conditions of the various changes occurring in society. Changes occurring in society cannot be separated from the difference between public relations. Society has a different variety from the aspect of culture, language, or religion, so as to address the challenges of these differences to be one liaison education relevant to the present. To face of changing conditions occurred in the community, then, Civics education is deemed appropriate to address the problems happened in a pluralistic society, so learning Civics education is more related to the context of human beings. Hence, each community is expected to have a well-behavior as citizens, for instance, they have the knowledge, skills, and self-awareness.

Civic education is tried to train the learners to comprehend and to handle any social problems appeared in community life, through adat badamai is able to train the learners having readiness and experience in solving social problems contained in society, so they could engage in creating banua.

Relating to adat badamai developed in Banjarmasin society, so the learning civic education contributes to establishing 
positive comprehension of adat badamai contained in Badamai culture. Custom badamai developing continuously in Banjarmasin society is introduced and applied early on the young generation, particularly the learners on primary education level until secondary education.

Custom badamai can be used as civics education reference in school because adat badamai have the essential elements contained in it, that is the value of democracy based on the divine, cooperation with others, resolving conflicts without violence, sensitivity the troubles of others, willingness and ability to participate in social life. Therefore, adat badamai through civics education need to be developed for learners as a basis to make a decision on the matter at hand.

In line with this, [6] pointed out the importance of teaching civics for students' high school, which is mastery, development dimension, and structure in learning civics very important for teachers for middle school students are expected to have the ability to think abstractly, partial or specialist, and analytical thinking. Therefore, to facilitate this need, teachers are supposed to prepare appropriate learning models supported by the ability to master the dimensions in teaching civics that knowledge, skills, values and attitudes and action. Adat badamai can be developed for students in middle school through the teaching of civics by using a variety of teaching methods that make the learner as an investigator while teachers act as a connector, so it may cultivate the learners attitude as responsible citizens, be capable to establish cooperation with others, respect others` opinions, understand and accept cultural differences in the community, resolve conflicts without violence, and foster sensitivity to social situations. Ref. [7] added that the teaching civics in schools to educate students, fosters good citizenship, the organization of teaching materials in accordance with the educational goals of students, and overview in understanding the various problems occurred around life. Therefore, teachers should prepare students to be able to participate actively in the development and interaction with the wider community.

Based on the statement above, adat badamai need to be developed within the scope of education because it is used as one of the topics in civics education for students. Learning Civics linked to adat badamai for Banjar community is expected to develop the knowledge, attitudes and learners' skills in building self-awareness as part of the community so that the learning of Civics is not only done in an effort to transfer knowledge from teacher to student, but teaching Civics using the local value contained in each region can form students to be democratic, participatory and understanding of local values citizens. Therefore, through custom badamai of Banjar community in their own environment can shape learners who are more sensitive to the problems occurred and experienced by society.

\section{CLOSING}

The value of adat badamai in the Banjarmasin community is universal values, likely family values, social values, moral values, unity values; the local value demanded is the values of jangan bacakut padadaan, which convey the meaning is not to fight or dispute among the relatives.
Custom badamai values are important to develop in the educational field, as it can be one of reference in the civic teaching and learning. Civic education associated with the adat badamai in Banjar community is expected to develop the process of knowledge, attitudes and learners`skills in building self-awareness.

\section{REFERENCES}

[1] Supardan, D, (2004). Pembelajaran sejarah berbasis Multikultural dan Perspektif Sejarah lokal, Nasional, Global untuk Integrasi Bangsa: StudiKasus Eksperimental terhadap siswa Sekolah Menengah Umum di Kota Bandung. Disertasi PPs UPI: Tidak diterbitkan.

[2] Ahmadi Hasan. (2008) Adat Badamai interaksi Hukum Islam dan Hukum Adat Pada Masyarakat Banjar, Yogyakarta: LK3

[3] Sapriya. (2008). Perspektif Pemikiran Pakar tentang Pendidikan Kewarganegaraan dalam Pembangunan Karakter Bangsa (Sebuah Kajian Konseptual-Filosopis Pendidikan Kewarganegaraan dalam Konteks Pendidikan IPS).Jurnal Acta Civicus Vol.1.No.2.April 2008.

[4] Budimansyah, D dan Karim Suryadi. (2008) PKN dan Masyarakat Multikultural, Bandung: Prodi PKn-SPs UPI

[5] Adisusilo, Sutarjo,2012. Pembelajaran nilai karakter kontrukturtivisme dan VCT sebagai Inovasi pendekatan pembelajaran afektif, Jakarta; Rajagrafindo Persada

[6] Sapriya (2011). Pendidikan IPS Konsep dan Pembelajaran, Bandung; PT Remaja Rosdakarya

[7] M. Numan Somantri (2001), Menggagas Pembaharuan Pendidikan IPS, Bandung: Rosaja Persada Karya 